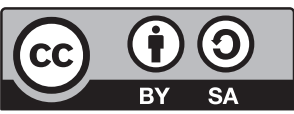

Ayalew Tilahun

Bahir Dar University, Ethiopia

Berhanu Simegn

Bahir Dar University, Ethiopia

Mulugeta Teka

Bahir Dar University, Ethiopia
(iD https://orcid.org/0000-0003-1564-3044

iD https://orcid.org/0000-0001-6192-9858

(iD https://orcid.org/0000-0002-9786-8871

\title{
Investigating Effects of Integrated Reading and Writing Skills Instruction on Enhancing Students' Critical Thinking Skills in EFL Classroom
}

\begin{abstract}
The primary concern of this study was to investigate the praxis of integrated reading and writing skills instruction on EFL learners' critical thinking development at Bahir Dar University. The study used a pre-test-post-test quasi-experimental design, and 96 English majoring students randomly assigned to $(n=48)$ experimental and $(n=48)$ control group took part in the study. Herein, the control group was instructed through a separated reading and writing approach and the experimental group learned through a newly designed integrated reading and writing way for 12 weeks concurrently with three sessions per week, and then, 25 pre-and post-tests of critical thinking questions were designed to assess students' critical thinking development. Here, Kappa inter-rater and split-half reliability tests were employed to compute the reliability and internal consistency of both tests, respectively. Finally, an independent t-test was employed to compute the data, and then the results revealed that both the control and experimental group were homogeneous regarding their level in the pre-tests of critical thinking skills. However, after the treatment, the study showed the supremacy of integrated reading and writing skills instruction over the conventional approach in enhancing students' critical thinking skills.
\end{abstract}

Keywords: integrated reading and writing instruction, language pedagogy, reading skills, writing skills, critical thinking skills 


\section{Introduction}

English is functional as a foreign language in Ethiopian context. As a result, it is not working as a viable Lingua Franca in everyday lives of the people outside of the EFL classroom. Thus, in the country, the opportunity of learning and practicing English outside the classroom is less frequent, and for this reason, particularly at the university level, students more often learn the language through reading and writing in their academic careers. Therefore, the instructional methods that the EFL teachers use in reading and writing would play vital roles in students' language and reasoning development, for the reason that reading and writing skills are two of the major skills that need to be taught efficiently to enable students to comprehend texts in a critical way. Consequently, reading analytically, composing text coherently and critical thinking skills are supposed to be the basis for the success of any university student, for these are very vital cognitive fundamentals that the learners must develop to explore the sphere of knowledge.

The contemporary thinking about the nature of reading and writing views the two skills as interdependent and transactive (Carson, 1993; Spack, 1998; Rossenblatt, 2004). Furthermore, these researchers point out that meaning is created through the transaction between the reader, the writer, and the text. Therefore, to equip students with the required capabilities, the teaching and learning activities which are employed in the university setting, particularly in EFL classrooms, should focus on enabling students to interact with a text through the process of integrating reading and writing activities because when learners involved in both analytical reading and writing skills in integrated ways, they also build up their critical thinking ability in their academic career. In this respect, researchers claim that reading extensively can improve students' writing abilities, and in the process of writing, the logical thinking abilities will be enhanced (Cavdar \& Doe, 2012). Here, instructors can no longer be information givers and students must learn thinking and reasoning skills to reach their fullest potential, and this can be done explicitly and directly in an integrated manner (Cobine, 1995; Fisher, 2001). Thus, involving students in the above activities encourages them to use the language for thinking rather than studying about the language. In a similar way, Facione (1990) asserts that "involving students in critical thinking activities helps them to become more mentally dynamic and decisive rather than passive receivers of contents in the classroom" (p. 3).

When reading and writing are integrated into classroom instruction, it enables students to think about effective comprehension strategies and engage in constructing meaning from a given genre. In line with this, researchers also claim that skill training and critical thinking can be reached simultaneously 
by integrating reading and writing skills in ESL/EFL classrooms (Richards \& Rodgers, 2001; Rosenblatt, 2004; Li \& Yang, 2014). In doing so, a reader tries to use higher cognitive skills to describe, respond, or interpret a reading text, and then a new interpreted text is produced in the process. Under these strategies, learners would be trained to organize their thoughts through writing. Likewise, the integration of reading into writing enables students to develop both critical thinking and critical literacy because it augments their ability to transform information for their own purposes in reading and to blend their prior awareness with another text in writing. Furthermore, put differently, both reading and writing skills are so closely linked, they mutually reinforce each other, and therefore, promote learning when they are integrated into classroom activities (Cobine, 1995). By the same token, Atkins et al. (1996), Cavdar and Doe (2012) all confirm that integrating the skills not only develops students' ability to express themselves, but it also develops students' thinking powerthey get mental training.

In the same vein, students become better readers, writers, and thinkers when they learn reading and writing together (Carson, 1993; Rosenblatt, 2004). Similarly, Fisher (2001) asserts that "students must develop thinking and reasoning skills to reach their fullest potential, and this can be done explicitly and directly in an integrated manner" (p. 17). Put briefly, making students engage in critical thinking helps them to maximize their involvement with the activities because critical thinking is an intellectually disciplined process of actively and skillfully conceptualizing, applying, inferring, interpreting, synthesizing, evaluating, reasoning activity during reading or writing communication (Paul $\&$ Scriven, 2008, p. 25). With this in mind, involvement in the above activities allows students use the language for thinking rather than studying about the language. Therefore, to make students fully engage in critical thinking, learners should get involved in both analytical reading and composing skills based on their reading. As students' knowledge and critical thinking develop through reading, their internal motivation to produce their own ideas through writing will also be enhanced. Furthermore, various scholars suggest that reading and writing skills are so closely linked that they mutually reinforce each other, and therefore promote learning when they are integrated into classroom activities (Alghonaim, 2018; Pysarchyk \& Yamshynska, 2015; Al-Dosari, 2016; Eun-Hee \& Myeong-Hee, 2020).

Thinking critically, as an essential part of the higher-order cognitive skills and the most important component of undergraduate EFL education, includes many other skills of higher-order mental processes like reasoning, reflective thinking, analysis, synthesis, inference, evaluation and decision making, creative thinking, and self-regulation. Thus, in relation to this, Elder and Paul (2009) recommend that every classroom activity with the aim to develop learners' critical thinking abilities should lead to an environment that enhances 
these basic skills in students' learning. Subsequently, in the light of the above view, integrated reading and writing instruction is where developmental reading and writing are taught in one course within a reduced period of time. In brief, all the above research claims imply that separating reading and writing skills in EFL classroom instruction has its own detrimental effects on enabling learners to make connections between these two skills in comprehending texts and critical thinking development.

Therefore, researchers and theorists recommend examining assumptions and reviewing educational practices, as current pedagogical thinking seems to be shifting away from traditional behaviorist model of teaching to constructivist views of learning whereby teaching is seen as transformative (Brandis \& Ginnis 1986, as cited in Richards \& Rodgers, 2001, p. 197). Furthermore, these researchers also suggest that skill training and critical thinking can be reached simultaneously by integrating reading and writing skills in ESL/EFL classrooms. Similarly, Graham and Hebert (2010) argue that "understanding a text encompasses writing about it; writing about a text should augment comprehension, for it provides learners with a tool for visibly and permanently recording, connecting, analyzing, personalizing and manipulating key ideas in text" (p. 13). These pedagogical positions range from the traditional skill-based, text-driven models to more holistic, process-oriented approaches associated with integrating the language arts. In the same way, Ferire (1984) and DuBrowa (2011) state that transformative and real literacy learning takes shape when the learner takes part in reading and writing activities and participates in the real-life insightful process. When the two language skills are integrated, it augments deep and careful thinking in meaningful ways. Furthermore, the integration of reading into writing enables students to develop both critical thinking and critical literacy that promote students' ability to transform information for their own purposes in reading and to develop text in writing.

With all this in mind, integrated reading and writing instruction is widely discussed in the ESL and EFL classrooms in a foreign context. However, in Ethiopia, though theoretically discussed, it is not practically implemented in the EFL classroom. For instance, in Bahir Dar University English courses like Basic writing skills and Communicative language skills are designed in an isolated skill approach. Furthermore, in secondary and preparatory English textbooks, reading and writing skills activities are presented on a separate basis. Why is that so? Is integrated reading and writing skills instruction not effective in the Ethiopian context? Can't it be practiced in the Ethiopian context? Therefore, testing integrated reading and writing skills instruction empirically plays a vital role to see its effectiveness for building critical thinking skills in the context of the university (undergraduate) education in Ethiopia. 


\section{Statement of the Problem}

In the context of EFL in Ethiopia, the curriculum and pedagogy of writing and reading courses have traditionally been designed on a separate basis. As a result, more emphasis is given to skill-based language activities. Moreover, tasks and activities have been designed usually focusing on one specific skill. For instance, in reading instruction, more emphasis is given to answering reading comprehension questions, vocabulary meaning, references, and so on. Indeed, these sorts of activities are important particularly for language practice, but their contribution to enable students to go beyond the literal meanings of the text is reduced. As a result, most learners neither understand the text fully nor give critical explanations about the text. Furthermore, in writing instruction classrooms, most often, writing lessons focus on writing activities on prescribed topics, and attention is too often paid to modeling correct grammatical and essayist forms instead of creating conducive environment for students to interact with language actively for authentic communicative purposes. Moreover, after students' writings, EFL instructors' main focus would be on correcting different kinds of writing mechanics like spelling errors, punctuation, wrong use of words, phrases, tenses and other related problems. Likewise, hand-written texts are evaluated on the accuracy of grammar rather than on content, style or creative expressions of ideas. As a result, students cannot get critical mental exercises through writing.

The above instructional approaches are very much emphasized in the traditional EFL teaching and curriculum provisions. Researchers like Taizad and Namaghi (2014) state that although segregated skills teaching may help students develop their knowledge of the language, its impact on enabling learners to use the knowledge in actual communication is less likely. Tsai (2006) also claims that the separate teaching of reading and writing skills approach is an obstacle in fluent learning of a foreign language. Likewise, Oxford (2001) states that segregated teaching emanates from the philosophy that sees successful L2 learning as a process departing from content learning. Furthermore, she explains that this philosophy is easier in practice, yet ineffective to warrant later whole language development. Similarly, Squire (1983) and Cavdar and Doe (2012) argue that failing to practice composing and comprehending, which are basically interrelated thinking oriented skills, impedes the efforts not only to teach students to read and write but also how to think.

With all these in mind, in the Ethiopian EFL context, as some past and recent local research findings and my close observation evidenced, the quality of critical thinking has been deteriorating in the EFL classroom, and then university students do not seem to meet the required competence. In his doctoral dissertation, Geremew (2009) reported that students' writing in 
different faculties of Addis Ababa University is weak in treating a given topic both in content and form. Furthermore, he noted that most professors require their students to critique books, term/research papers, articles, academic essays, films, and formal reports related to the content of their courses. These activities require students to think critically about how they approach problems, questions, issues, and how they apply affective dispositions such as open-mindedness and diligence in seeking relevant information, being systematic in analyzing information, and inferring that can reasonably be drawn from facts. However, students are not capable of doing these sorts of activities.

In the same way, Dawit (2008) claims that even though the Ministry of Education (1994) asserts that active learning methods or student-centered teaching should govern educational practices in schools and universities, Ethiopian educational system continues to provide students with the traditional model of instruction. Furthermore, he adds that the faulty everyday reasoning and poor argumentation skills used by most students (both orally and in writing) indicate that even a college/university education appears to have a limited effect on graduates' critical thinking abilities, including making reasonable interpretations of texts. Adege (2009) conducted research on "Critical Thinking Pedagogy in EFL classrooms at Jimma University" and came to the conclusion that the majority of EFL instructors (71\%) agreed that critical thinking is an important goal of their instructional objectives and/or practices, but only $2 \%$ of the total number of university EFL teachers bring explicit modeling of critical thinking in their classroom instruction and 5\% of them bring critical thinking assessment into their assignments and examinations. Therefore, the study shows that critical thinking is given less emphasis, or it is a neglected aspect in EFL classrooms in Ethiopia.

Wondifraw (2018) also conducted a study to analyze the effect of infusing intellectual standards of critical thinking on students' critical reading performance. In his study, assessing EFL students' attitudes and practices in reading academic texts critically and exploring students' level of critical reading performance were aimed to supplement the analysis. Finally, it was found that most English language students had inadequate insights on critical reading tasks and inquisitive strategies, and the practices of critical reading activities were not engaging. Likewise, the students' critical reading performance was found to be unsatisfactory. In sum, all the above research results show that there is a gap in instructional practices that need to be addressed particularly in building critical thinking skills.

Concerning reading and writing integrated instruction, there are many recent research works that have been conducted in a foreign context. For instance, $\mathrm{Li}$ and Yang (2014) conducted a study on the effects of reading-to-write on critical thinking skills and concluded that practicing reading to write in the 
classroom helps students to shift from the passive reception of knowledge to an active seeking for knowledge and also to move from the rote learning of the text to the practical use of the knowledge in solving problems. However, the research conducted in a Chinese educational setting which differs from the Ethiopian context. Similarly, Al-Dosari (2016) carried out a study on the effects of integrated reading and writing on the quality of writing. The results of the study showed a statistically significant improvement in writing, but the researcher did not address critical thinking skills. Likewise, Hailah (2020) conducted a study on the effectiveness of integrating reading and writing pedagogy in the EFL setting and teachers' perception, and he came to the conclusion that integrated reading and writing had a significant impact on students' reading abilities and writing proficiency over a short period. However, he did not address critical thinking skills.

In fact, in the Ethiopian context, there are not many pieces of research that have been conducted on the effects of integrated reading and writing instruction in the EFL classroom. However, Desta (2019) investigated the effects of integrated reading-and-writing practice on EFL learners' performance and self-efficacy of reading comprehension and summary writing with grade eight students. The researcher applied tests and interviews to collect the required data. Finally, he came up with the conclusion that integrated reading-and-writing skill instruction has a positive influence on students' reading comprehension, summary writing, and self-efficacy. However, the researcher did not investigate its effects on students' critical thinking skills achievement.

Likewise, Alemu (2015) conducted a study on the integrated content-based instructions in teaching English reading skills to grade 11 students. He used an interview, classroom observation, and document analysis to collect the data. Finally, he came to the conclusion that teachers had high theoretical orientations about integrated instruction, but because of a number of impediments in the environment related to school, integrated content based instruction could not be implemented in language teaching in reading classrooms. However, the researcher's focus was only on assessing the implementation of integrated content-based instruction on teaching reading skills, not on students' critical thinking.

Therefore, as the literature review and different research evidence imply, in the practice of integrating reading and writing skills, readers must be able to interact with text to construct meaning and in the process of gaining meaning, they should get involved in writing in response to comprehension exercises. Learners should interact with a text to comprehend and compose a text in various forms based on the text they have read. For instance, in the process of reading comprehension instruction, students are supposed to respond to comprehension exercises by writing their predictions, identifying the main idea of paragraphs, paraphrasing, summarizing, interpreting texts, analyzing activities, 
explaining, inferring information, writing the gist of the text, and so on. Finally, students should be involved in connecting activities like text-to-self, text-totext and text-to-world, connecting what students read to what they are familiar with, which is a part of the transaction readers use to comprehend and analyze the text.

Challenging students to think critically about academic subjects and to develop the reasoning abilities they need to deal successfully with real-world reasoning tasks in life is rarely practiced in EFL context in Ethiopia. This observation has, therefore, further motivated this researcher to empirically examine if the university undergraduate students in Ethiopia would be better able to demonstrate critical thinking abilities, and use these same abilities to do better academically in their learning, and in everyday reasoning tasks after having received a semester-long specific integrated reading and writing skills instruction.

Hence, the major concern of this study is to investigate the effectiveness of an integrated reading and writing instructional approach on undergraduate students' critical thinking skills development in the EFL classroom. As far as the researcher's knowledge is concerned, no research of this sort has been conducted in Ethiopia so far. Therefore, this research would be the first and new in its kind, and it would attempt to add to the knowledge in the field and try to fill the gap in this respect.

\section{Objectives of the Study}

Teaching and learning reading and writing skills in an integrated way is basic in contemporary language theory and pedagogy. Furthermore, the theory claims that readers must be able to transact with the text to construct the meaning and, in the process of gaining meaning, the students would get involved in writing in response to open comprehension exercises. Therefore, the main objective of this study is checking empirically whether the integrated reading and writing skills instructional approach has an effect on students' critical thinking development in the Ethiopian EFL context. Thus, in this study, the following research questions were formulated:

1. Is there a statistically significant difference between the achievement of the experimental group and that of the control group in their critical thinking skills before the treatment?

2. Is there a statistically significant difference between the achievement of the experimental group and that of the control group in their critical thinking skills after the treatment? 
The Null Hypotheses

1. There is no statistical difference between the achievement of the experimental and the control group in their critical thinking skills achievement before the treatment.

2. There is no statistical difference between the achievement of the experimental and the control group in their critical thinking skills achievement after the treatment.

\section{Research Design}

In order to address the objectives of this research, experimental research design was employed, and the kind of experiment was a quasi-experiment. This type of experimentation is helpful to examine the effects of an independent variable on dependent variables. Moreover, the quasi-experiment plays a crucial role in the environment where it is not possible to control all other factors that might affect the results. In this experimentation, two intact groups of freshmen who take Communicative English skills courses I participated. They were assigned randomly to control experimental groups in order to avoid any experimental bias.

\section{Scope of the Study}

This study was delimited to first-year undergraduate students of Bahir Dar University. The reason for delimiting this study to the first-year undergraduate students was mainly that these students were supposed to study the course Communicative language skills. The assumptions of the course are that it would help them to maximize their communicative and reasoning competence in their oral and written communication. Furthermore, in this stage, students are expected to work at a higher level (i.e., to read more critically, to write more analytically, to think more conceptually with higher-order thinking skills than ever before).

On the other hand, the researcher has chosen these groups of students for some other basic reasons, too. The first one is that the researcher had tangible corpus evidence at hand on the existence of the problems in comprehending texts, composing and critical thinking performance that had been collected through assignments and examinations at various times from the same level of 
students in the first semester. The corpus documents that the researcher collected from the groups of students were the main trigger that instigated him to conduct this experimental research with these groups of students.

\section{Data Collection Instruments}

In this study, the test was employed as the main data collection instrument. Pre- and post-tests were employed to collect the required data. The tests were adapted from the TOEFL tests by the researcher in collaboration with curriculum experts at the university. The reasons why the researcher adapted the reading passage from TOEFL with some modifications were that the tests are standardized. Pierce (1994) notes that TOEFL tests are standardized, highly secure and internationally administered for assessing the language proficiency level of foreign language speakers. Furthermore, the same author points out that TOEFL tests have high reliability and validity. They have substantial reliability estimates between 0.87 and 0.90 (Pierce, 1994).

The test also included questions that measured students' critical thinking abilities on the basis of the texts. At this point, the critical thinking questions were prepared in an open-ended question format. In sum, 25 critical thinking questions were prepared for the test. The tests were prepared and assessed based on Facione's (1995) critical thinking model. Facione (1995) states that a person engaged in critical thinking uses a core of self-regulated cognitive skills like interpretation, analysis, inference, evaluation, and explanation to form logical reasoning and judgments (p. 3). Herein, the first test was a pre-test that was given to both control and experimental groups to make sure that the two groups had equivalent capacities before the treatment. The second test was a post-test that had been given to both groups at the end of the intervention to check whether the intervention had an effect on the experimental group. All the above-listed assessment models were employed to assess students' critical thinking skills except 'evaluation'. Assessing students' 'evaluation' skill was not used in this specific study since it is highly exposed to subjectivity, as proved in the pilot study. Hence, it was not found convenient in this particular study. Finally, the results of the pre-test and post-test scores were analyzed using an independent T-test. 


\section{The Reliability of the Tests}

In order to ensure the reliability of the pre-test of the critical thinking questions, two university TEFL professors rated each item to check whether the tests are relevant, appropriate, and consisting of adequate items for the intended purpose and then Cohen's kappa statistical measurement was employed to compute the results of the raters' agreement. So, kappa coefficient measure of agreement between the two TEFL professional raters regarding the pre-test of critical thinking lies in the category of 'very good' was $88 \%$, and the value of the kappa measure of agreement is 0.638 . Therefore, according to Koch's benchmark (1977) percent agreement rate classification, the result obtained by the kappa coefficient measure of agreement between the two raters can be considered as perfect agreement, and then the test was used for the intended purpose. Therefore, the pre-test questions which are designed to measure students' critical thinking were reliable.

Similarly, 25 critical thinking questions were rated by two TEFL professionals: the Cohen's kappa coefficient measure of agreement between the two TEFL professional raters regarding the post-test critical thinking questions which lie in the category of 'very good' was $92 \%$, and the value of the kappa measure of agreement was -0.569 . Therefore, according to Koch's benchmark (1977) the percent agreement rate classification, the result obtained from the kappa coefficient measure of agreement between the two raters can be considered as a perfect agreement. As a result, the questions were found reliable for the intended purpose.

\section{Internal Consistency of the Tests}

In the same way, the internal consistency of both the pre- and post-tests of critical thinking skills' questions were computed using split-half reliability tests. Based on this, the value of the half-split reliability of the pre-tests of critical thinking questions' correlation between forms is 0.309 , and the value of the Spearman-Brown coefficient is 0.871 . Similarly, the value of the post-test critical thinking correlation between forms is 0.39 , and the Spearman-Brown coefficient is 0.85 . This indicates that the Spearman-Brown coefficient or the aggregate result exceeds the value of the correlation between forms in both tests. Therefore, based on the above analysis of reliability interpretation, the value of the pre- and post-tests' results of this data is reliable. In general, the values of all types of tests' half-test reliability results revealed that the tests' internal consistency was reliable for the intended purpose. 


\section{The Validity of the Tests}

As stated above, the tests were adapted from the TOEFL exams. In order to determine whether the reading passages matched the students' level, Gunning Fog Index Formula was used to measure the difficulty level of reading texts. The difficulty level of the pre- and post-tests were 11 and 12 respectively. Gunning (1968) recommends that difficulty levels of reading passages between 8 and 13 are considered as appropriate for undergraduate students. Furthermore, to assess the validity of the tests, the designed test was given to two TEFL university professors to check whether the test is relevant, appropriate, and consisting of adequate items for the intended purpose. Moreover, the tests have been assessed whether they have a mix of easier and harder questions. In all the above criteria, the tests were rated by two professionals in the categories of very good, good, or poor. Finally, the rating results were computed using the kappa measure of agreement. Apart from the two professors, the test was also given to two of research advisors to be commented on and checked whether the tests consist of the required face and content validity for the intended purpose. Eventually, the advisors' and two of the professors' comments were followed in the final preparation of the tests. Lastly, with all amendments, the tests were administered to collect the required data.

\section{Procedures of the Study}

As discussed above in the research design, students from two EFL groups were assigned randomly as control and experimental groups. The trained instructor was assigned to teach Communicative language skills I in these groups. In this study, the main focus area is reading and writing. Other language learning activities were shared by both groups. Therefore, in the conventional approach, students often read the text and do a set of activities focusing on comprehension, while the instructor's feedback would focus on correcting students' errors to the given answers. Similarly, writing would be done or practiced on prescribed topics focusing on end products of the handwritten text, and then the instructor's feedback would concern the grammatical accuracy.

However, the newly designed integrated reading and writing instructional procedure was implemented for the experimental group with the following three steps. Firstly, apart from brainstorming discussions, there were writing before reading activities like predicting contents in the form of paragraphs 
or writing a short paragraph on different sayings related to the texts before going through the texts (Write-before-you-read activities). Secondly, the students were supposed to write their response to the literal and open-ended questions like comparing their prediction, identifying the main idea of paragraphs, paraphrasing, summarizing, interpreting texts, analyzing, explaining, inferring information, writing the gist of the text (Read and respond through writing activities). Finally, the students were involved in connecting activities like text-to-self, text-to-text and text-to-world activities (Write-text connecting activities). Indeed, when the students failed to implement the above cognitive strategies by themselves, the instructor was supposed to guide and teach explicitly each selected strategy until the students mastered it and worked independently, and the instructor's feedback was given through reflective observation.

The implementation of the instructional strategy for both the control and experimental group lasted for 12 weeks with three sessions per week and was held from October 1, 2019, to December 30, 2019. Finally, a critical thinking test was given to the two groups to see if there is a change in students' critical thinking results. Eventually, the tests were corrected by two different TEFL instructors to avoid unintended biases in correcting the subjective items, and the results the students obtained in the 25 critical thinking questions were used for analysis. Finally, the two instructors' average score was taken for analysis, and then it was analyzed and computed through an independent t-test to see if a significant difference existed between the groups in terms of critical thinking skills development.

\section{Data Analysis, Findings of the Study, and Discussions}

In this part, data analysis, findings, and their discussion of the study are presented in accordance with the students' critical thinking skills' test results.

RQ; Is there any significant difference between the two randomly selected intact groups of students in terms of critical thinking skills before the treatment? 
Table 1

Descriptive and inferential statistics of the experimental and control groupspre-test results of students' critical thinking skills

\begin{tabular}{|c|c|c|c|c|c|c|c|c|}
\hline Group & & $\mathrm{N}$ & Mean & $\begin{array}{l}\text { Std. } \\
\text { Deviation }\end{array}$ & $\mathrm{t}$ & $d f$ & $\begin{array}{l}\text { Sig. } \\
\text { (2-tailed) }\end{array}$ & $\begin{array}{l}\text { Cohen's } \\
\text { d effect } \\
\text { size }\end{array}$ \\
\hline \multirow[b]{2}{*}{ Inference } & control group & 48 & 11.770 & 2.746 & -2.063 & 94 & .072 & 0.421 \\
\hline & $\begin{array}{l}\text { experimental } \\
\text { group }\end{array}$ & 48 & 12.791 & 2.052 & & & & \\
\hline \multirow[b]{2}{*}{ Interpretation } & control group & 48 & 12.250 & 2.693 & -.671 & 94 & .504 & 0.136 \\
\hline & $\begin{array}{l}\text { experimental } \\
\text { group }\end{array}$ & 48 & 12.583 & 2.142 & & & & \\
\hline \multirow[b]{2}{*}{ Explanation } & control group & 48 & 12.583 & 3.167 & -.868 & 94 & .388 & 0.177 \\
\hline & $\begin{array}{l}\text { experimental } \\
\text { group }\end{array}$ & 48 & 13.125 & 2.943 & & & & \\
\hline \multirow[b]{2}{*}{ Analysis } & control group & 48 & 14.791 & 3.395 & -.530 & 94 & .598 & 0.108 \\
\hline & $\begin{array}{l}\text { experimental } \\
\text { group }\end{array}$ & 48 & 15.125 & 2.733 & & & & \\
\hline
\end{tabular}

As shown in Table 1, there were 48 participants both in the control and experimental groups. The mean scores of the control and experimental groups in terms of each critical sub-skill is presented sequentially. Among the critical thinking elements, inference is one of the sub-skills. The mean score of the experimental (group 2) $(\mathrm{M}=12.791 ; \mathrm{SD}=2.052)$ was slightly higher than in group $1(\mathrm{M}=11.771 ; \mathrm{SD}=2.746)$. Here, the two groups' mean difference is -1.0208 which is an insignificant means difference. Thus, the results show that students do not differ significantly in inferring before the treatment. Likewise, an independent-samples t-test revealed no statistically significant difference between group 1 (the control group) and group 2 (the experimental) mean scores since t $(94)=-2.063$; the Sig. (2-tailed) value $=.072, \mathrm{P}>0.05$. In the same way, the effect size is Cohen's $d=0.421$ signifying a medium effect size. Therefore, the results show that there is no statistically significant difference between the two groups in their inference skills before the treatment.

Correspondingly, in terms of students' interpretation, both groups had almost equal mean scores on the pre-test. The mean difference between the groups is -.333 . Therefore, between the two groups, a non-significant mean difference was obtained. This indicated that the two groups were equal before the treatment. Moreover, the result of an independent samples t-test signified that there is no significant difference between the experimental and control groups in their interpretation. The $\mathrm{t}(94)=-.671$; the Sig. (2-tailed) value $=.388$, $P>0.05$. In the same way, the result of the effect size is Cohen's $d=0.136$, specifying a small effect size. Therefore, there was no significant difference 
between the two groups of students in their interpretation achievement before the treatment.

Similarly, students' explanation achievement mean score of group 2 $(\mathrm{M}=13.125 ; \mathrm{SD}=2.943)$ was slightly higher than that of group $1(\mathrm{M}=12.58$; $\mathrm{SD}=3.167)$. The difference between the two groups in their mean scores is -.541 . So, the difference margin is very narrow, and this portrays that the two groups did not differ in their explaining achievement before the treatment. The independent samples t-test result shows that there is no significant difference between the experimental and the control group in their explanation achievement since t $(94)=-.868$; the Sig. (2-tailed) value $=.388, \mathrm{P}>0.05$. Likewise, the result of the effect size is Cohen's $d=0.177$ signifying a small effect size. With this in mind, the statistical evidence showed the absence of statistically significant difference between the two groups in terms of their explanation achievement.

Likewise, students' achievement in analyzing texts was also compared. Based on this, the mean scores of group 2 was $(\mathrm{M}=15.125$; $\mathrm{SD}=2.733)$ and group $1(\mathrm{M}=14.791, \mathrm{SD}=3.395)$ respectively; their mean difference is 1.333 which is insignificant. The results of the independent samples t-test result showed the absence of a significant difference between the control and experimental groups scores in terms of their analysis achievement since t (94) = -.530 ; the Sig. (2-tailed) value $=-.333, \mathrm{P}>0.05$. In the same way, the result of the effect size is Cohen's $d=0.108$, showing a small effect size. Therefore, from these results, it is possible to conclude that the two groups of students did not differ in their analyzing achievement before the treatment.

The independent sample test results also confirm that the groups' mean differences are not statistically significant in all the above listed critical skill components in the pre-test results or before the treatment. Therefore, there is no significant variance between the experimental and control groups in terms of inferences, interpretations, explanations, and analyses skills' achievement before the treatment. As a result, the null hypothesis is accepted.

\section{Critical Thinking Post-test Result Comparison between the Control and Experimental Groups}

The following research question and corresponding null hypothesis were addressed in this section:

RQ: Is there a statistically significant difference between the achievement of the control and experimental groups of students in their critical thinking skills after the treatment? 
Null hypothesis (H01): There is no statistical difference between the achievement of the control and experimental groups in their critical thinking skills achievement after the treatment.

Table 2

Descriptive and inferential statistics of the experimental and control groupspost-test result of students' critical thinking skills

\begin{tabular}{lllllllll}
\hline Group Statistics & & & & & & & & \\
\hline Group & & $\mathrm{N}$ & Mean & $\begin{array}{l}\text { Std. } \\
\text { Deviation }\end{array}$ & $\mathrm{t}$ & $\mathrm{df}$ & $\begin{array}{l}\text { Sig. } \\
\text { (2-tailed) }\end{array}$ & $\begin{array}{l}\text { Cohen's } \\
\text { d effect } \\
\text { size }\end{array}$ \\
\hline \multirow{3}{*}{ Inference } & Control group & 48 & 12.25 & 3.131 & -3.634 & 94 & .000 & 0.74 \\
\cline { 2 - 9 } & $\begin{array}{l}\text { Experimental } \\
\text { group }\end{array}$ & 48 & 14.5 & 2.931 & & & & \\
\hline \multirow{3}{*}{ Interpretation } & Control group & 48 & 12.08 & 4.556 & -5.187 & 94 & .000 & 1.05 \\
\cline { 2 - 9 } & $\begin{array}{l}\text { Experimental } \\
\text { group }\end{array}$ & 48 & 16.33 & 3.385 & & & & \\
\hline \multirow{3}{*}{ Explanation } & Control group & 48 & 12.25 & 4.397 & -5.762 & 94 & .000 & 1.05 \\
\cline { 2 - 9 } & $\begin{array}{l}\text { Experimental } \\
\text { group }\end{array}$ & 48 & 17. & 3.643 & & & & \\
\hline \multirow{3}{*}{ Analysis } & Control group & 48 & 14.25 & 3.491 & -5.184 & 94 & .000 & 1.176 \\
\cline { 2 - 9 } & Experimental & 48 & 18.33 & 4.193 & & & & \\
\hline & group & & & & & & & \\
\hline
\end{tabular}

As it is clearly displayed in Table 2, the number of students in group 1 (control group) and group 2 (experimental group) is equal to 48 participants. The table shows the results of students' critical thinking sub-skills like inference, interpretation, explanation, and analysis after the treatment. Inference is one of the sub-skills. As displayed in the table, there is a significant difference between the experimental $(\mathrm{M}=14.5 ; \mathrm{SD}=2.931)$ and the control group $(\mathrm{M}=12.25 ; \mathrm{SD}=3.131)$ in inferring information from a given reading text. As a result, the mean difference between the two groups is -2.25 . The independent sample t-test result depicts that there is a significant difference between the experimental and control groups of students in text inference since the $\mathrm{t}(94)=-3.634$; Sig (2-tailed) value $=000, \mathrm{p}<0.05$. Furthermore, the result of the effect size shows that Cohen's $d=0.74$, specifying a strong effect. Therefore, the result of the independent samples t-test indicates that there is a statistically significant difference between the experimental and the control groups of students on the inference post-test. In other words, the experimental group of students scored higher than the control group in terms of inferring information after the intervention. In general, all the above descriptive and inferential statistical data confirm that the intervention that had been implemented in the 
experimental group in the EFL classroom had a positive effect on students' inference skills.

By the same token, as the data demonstrated in Table 2 shows, there is a significant mean difference between the experimental $(\mathrm{M}=16.331$; $\mathrm{SD}=3.385)$ and the control group $(\mathrm{M}=12.083$; $\mathrm{SD}=4.556)$ in text interpretation in the post-test results. Thus, the mean difference between the two groups is -4.25 . So, this descriptive statistics result justifies the claim that the experimental group surpassed the control group in interpreting on the critical thinking skills post-test due to the intervention. This is supported by the independent sample t-test result which shows that there is a significant difference between the experimental and control group in text interpretation; the Sig. (2-tailed) value $=000, p<0.05$. Moreover, the result of the effect size shows that Cohen's $d=1.05$, specifying a strong effect. Thus, the results of the independent samples t-test verify that there is a statistically significant difference between the experimental and control groups in interpretation due to the intervention. In brief, the experimental group scored higher than the control group on critical thinking post-test. This clearly demonstrates that integrating reading and writing intervention that had been practiced by the experimental group in the EFL classroom had a positive effect on their interpretation skills.

The data exhibited in Table 2 shows that there is a significant mean difference between the experimental $(\mathrm{M}=17 ; \mathrm{SD}=3.643)$ and the control group $(\mathrm{M}=12.25 ; \mathrm{SD}=4.397)$ with respect to text explanation. Hence, the mean difference between the two groups is -4.75 . So, this result attests that the experimental group exceeded the control group on the text explaining achievement on the post-test after the intervention. This result is verified by the independent sample t-test result that shows a significant difference between the experimental and control groups on text explanation since the $t(94)=-5.762$; the Sig. (2-tailed) value $=000, \mathrm{p}<0.05$. Furthermore, the effect size shows that Cohen's $d=1.176$, showing a strong effect. Therefore, the results of the independent sample t-test reveal that there is a significant difference between the experimental and the control group in the explanation achievement in the critical thinking skills post-test. Generally, the evidence obtained from these statistical data shows that there is statistically significant difference between the two groups of students on explaining texts in the critical thinking skills post-test result. In a nutshell, it is possible to conclude that the experimental group's test result surpassed the control group text explanation achievement as a result of reading and writing integrated instructional intervention.

Table 2 also shows that there is a mean difference between the experimental $(\mathrm{M}=18.333 ; \mathrm{SD}=4.193)$ and the control group $(\mathrm{M}=14.250 ; \mathrm{SD}=3.491)$ in text analyses in the post-test results. Consequently, the mean difference between the two groups is -4.083 . Hence, these results assert that the experimental group outscored the control group on text analyzing achievement after the intervention. 
Also, the independent sample t-test analysis shows that there is a significant difference between the experimental and control group on text analysis for the $\mathrm{t}(94)=-5.184$; the Sig. (2-tailed) $\mathrm{p}$ value $=000$. Moreover, the effect size shows that Cohen's $d=1.058$, indicating a strong effect. Thus, the statistical evidence obtained from the independent sample t-test pointed towards the idea that there is a statistically significant difference between the experimental and the control group in the text analysis achievement on the critical thinking skills post-test. Altogether, the descriptive and inferential statistical data endorse that there is a statistically significant difference between the experimental and control group in text analysis skills. In other words, the experimental group scored higher than the control group in terms of analyzing texts on critical thinking skills post-test as a result of the intervention. This clearly indicates that the treatment that had been implemented in the experimental group in the EFL classroom had brought a positive effect on students' analytical skills. To sum up, all these data would seem reasonable to point to the likelihood that the null hypothesis is rejected.

\section{Discussion}

In this part, to investigate the existence of the difference between the two groups, a 12-week integrated reading and writing instructional intervention was implemented on the experimental group and the traditional reading and writing segregated approach on the control group. Finally, the two groups' critical thinking pre-test and post-test results were compared. Based on this, the students' pre-test critical thinking result was homogeneous before the treatment. However, the post-test results demonstrate that the students in experimental group performed well $(\mathrm{p}<.05)$ in terms of various aspects of critical thinking like inference, interpretation, explanation, and analysis skills compared to the control group whose scores on each of these scales showed a lower result.

Furthermore, the experimental groups of students' post-test question items were deeply analyzed to see which aspects of the critical thinking skills the experimental group did better than the control group. The analysis of the experimental group students' results revealed that they manifested better results in inferring information like constructing reasonable meaning from a text, identifying the author's purpose or the intended message he/she wants to convey, identifying information that was not clearly stated in the text, and framing syntheses of related ideas into a coherent view and so on. Similarly, the experimental group was good at interpreting texts, identifying key ideas 
from the text, paraphrasing a text, guessing the meanings of unfamiliar terms, identifying the purpose of the text, and so on. Also, the experimental group's results at explaining texts like clarifying, summarizing, describing, justifying were much better than the control groups. Likewise, the experimental group was good at analyzing texts by identifying main ideas from a text, finding a relationship between texts, identifying similarities and differences between claims in the specified text, finding the relationship of sentences or paragraphs, and so on. Therefore, the results imply that the treatment that had been implemented in the experimental group in the EFL classroom had brought a positive effect on students' critical thinking skills.

The results of this experimental study substantiate the results obtained by Li and Yang (2014) who state that reading to write practice helps students to shift from passive reception of knowledge to active seeking for knowledge and to move from rote learning to the practical use of knowledge in solving problems. The results obtained in the research also confirm that students could infer, interpret, explain, and analyze the required information on their own more effectively than the control group. Similarly, the result is also consistent with Hirvela's (2004) proposition that using both writing and reading skills in harmonious integration in EFL instruction enhances students' understanding, composing skills, and the ability to look at things critically. Likewise, the findings also agree with the claims of Graham and Hebert (2010) who argue that understanding a text involves writing about it, and writing about a text should enhance comprehension, for it provides students with a tool for visibly and permanently recording, connecting, analyzing, personalizing and manipulating key ideas in a text. Therefore, the results of the current experimental group's critical thinking improvement concurred with the above findings.

The findings of the current study imply that when reading and writing are integrated into instruction, it helps students to combine input and output together at the same time in the EFL classroom. Reading is input, and writing is output, therefore, when students read a text, there are contents and language elements that they can explore in the text. Thus, when they construct written responses for an open-ended comprehension, they apply both comprehension and composition concurrently. In doing so, they show their understanding of what they have read in the text, for writing is important for thinking. When they write in response to the text, the knowledge they get from the text can be transformed into their writing. The results obtained in this research also confirm this reality. In contrast, when reading and writing are taught separately in classroom instruction, students do not connect input and output together. Rather, their focus will be on discrete skills, and there is no way to use language in a holistic way and, as a result, it hampers students' thinking development. Therefore, integrating reading and writing in instruction has immense benefits for students' critical thinking advancement. Moreover, the results of the cur- 
rent study also affirm that integrating reading and writing skills instruction to enhance learners' critical thinking can be also practiced in the Ethiopian EFL setting.

\section{Conclusion}

In this study, the data collected quantitatively revealed that learners who received an integrated reading and writing instruction demonstrate higher critical thinking skills than the learners who learned in the conventional way. The intervention boosted students' ways of thinking in various dimensions particularly, on inference, interpretation, explanation, and analysis respects. In a nutshell, these results show that integrating the two skills gives students more opportunities to construct their own learning than the conventional approach does, and it also encourages them to be a self-reliant learner and help them develop their self-confidence to take responsibility for their own learning, especially with respect to foreign language learning. Moreover, the findings show that integrated reading and writing instruction into EFL is a good predictor of critical thinking skills improvement for learners as it transforms them from passive to active readers and writers, and also maximizes students' language use instead of simple memorization of facts and grammar rules. As the results of the students' improvement in the critical thinking post-test indicate, integrating the two skills empowered the students to practice the critical thinking components in meaningful ways. The results are in line with DuBrowa's (2011) findings that the integration of reading and writing enables students to develop both critical thinking and critical literacy that promote students' ability to transform information for their own purposes.

Furthermore, EFL instructors should be aware that implementing reading and writing integrated instruction helps learners to be immersed in reading and writing which demand the use of the two language skills at a time, and then it may make learners be motivated to use authentic language and enables them to interact naturally with the target language and develop implicit knowledge as well. Moreover, it develops students' learning in all disciplines because it requires them to become more actively engaged in what they are learning and with that engagement, greater academic success will come and that in turn increases students' motivation. In the same way, it is more relevant to teach reading and writing in an integrated way while teaching communicative language skills in higher institutions to enhance students' critical thinking in the EFL classroom. 
Finally, the researchers of this study recommend other researchers to continue to explore the potential effects of this pedagogical approach at different grade levels, using multiple data collection instruments.

\section{Limitations of the Study}

There were some limitations that affected this study. Some were associated with the area of sample and sampling; the sample in this study was handpicked on purpose from one university which may not represent most students from all universities in Ethiopia; however, this is done by considering that the students in this university can possibly come from every corner of the country. Furthermore, though every effort has been made to investigate this theme as thoroughly as possible, it is impossible to claim confidently that the researchers were able to scrutinize every single bit of areas in comprehensively finding all possible researches on this respect.

\section{References}

Alemu, A. (2016). The effects of explicit instruction in critical thinking on student achievement in writing. (Unpublished PhD Dissertation). Addis Ababa University.

Al-Dosari, H. (2016). Effects of an integrated reading and writing approaches on improving writing skills of EFL students. Dirasat Educational Sciences, 43 (1), 761-771. https://doi.org/10.12816/0030028

Alghonaim, A. S. (2018). Explicit ESL/EFL reading-writing connection: An issue to explore in ESL/ EFL Settings. Theory and Practice in Language Studies, 8(4), 385-392. https://doi.org/10.17507/tpls.0804.04

Carson, J., \& Leki, I. (1993). Reading in the composition classroom: Second language perspective. Heinle \& Heinle. https://doi.org/10.1017/S027226310001336X

Cavdar, G., \& Doe, S. (2012). Learning through writing: Teaching critical thinking skills in writing assignments. PS: Political Science and Politics, 45 (2), 298-306. https://www.jstor.org/stable/i40070009

Cobine, Gary R. (1995). Writing as a response to reading. ERIC Digest, ED386734. https://catalogue.nla.gov.au/Record/4117942

DuBrowa, M. (2011). Integrating reading and writing: One professor's story. Journal of Research and Teaching in Developmental Education, 28(1), 30-33. https://eric.ed.gov/?id=EJ960411

Elder, L., \& Paul, R. (2009). Critical thinking: Strategies for improving student learning. Journal of Developmental Education, 32(3), 40. https://eric.ed.gov/?id=EJ868672 
Eun-Hee, N., \& Myeong-Hee, S. (2020). Teaching activities and students' preferences in integrated English reading and writing classes. English Teaching, 75 (2), 69-91. https://doi. org/10.15858/engtea.75.2.202006.69. http://journal.kate.or.kr

Facione, P. A. (1992). The California critical thinking skills test. Academic Press. https://citeseerx.ist.psu.edu/viewdoc/download?doi=10.1.1.131.8583\&rep=rep1\&type=pdf

Fisher, A. (2001). Critical thinking: An introduction. Cambridge University Press. https://www. worldcat.org/title/critical-thinking-an-introduction/oclc/47983908

Geremew, L. (2009). A study on the academic writing requirements: Four departments in Focus. (Unpublished $\mathrm{PhD}$ dissertation). Addis Ababa University.

Getu, A. (2015). Assessment of integration of content-based instruction in teaching English. (Unpublished PhD dissertation). Addis Ababa University,

Graham, S., \& Hebert, M. A. (2010). Writing to read: Evidence for how writing can improve reading. A Carnegie corporation time to act report. Washington, DC. Alliance for Excellent Education. https:/www.carnegie.org/publications/writing-to-read-evidencefor-how-writing-can-improve-reading

Haregewoin A. (2008). The effect of communicative grammar on the accuracy of academic writing. (Unpublished $\mathrm{PhD}$ dissertation). Addis Ababa University.

Hao, X., \& Sivell, J. (2002). Integrating reading and writing in EFL composition in China. Paper presented at the annual meeting of the Canadian association of applied Linguistics: Humanities and social sciences. Congress, Toronto. https://files.eric.ed.gov/ fulltext/ED468599.pdf

Hailah, A. (2020). Evaluating the effectiveness of integrating reading and writing pedagogy in EFL setting and teachers' perceptions. English Language Teaching, 13(5), 177-190. https://doi.org/10.5539/elt.v13n5p177

Hirvela, A. (2004). Connecting reading and writing in second language writing instruction. The University of Michigan Press.

Kintsch, W., \& Vipond, D. (1979). Reading comprehension and readability in educational practice and psychological theory. In L. G. Nilsson (Ed.), Perspectives on memory research (pp. 329-365). https://philpapers.org/rec/KINRCA-3

Landis, J. R., \& Koch, G. G. (1977). The measurement of observer agreement for categorical data. Biometrics (March 1977), 33(1), 159-174. PMID: 843571.

Li, Z., \& Yang, C. (2014). Reading-to-write: A practice of critical thinking. Journal of Arts and Humanities 3(5), 67-71.

Nigusse, D. (2019). The effects of integrated reading-and-writing practice on EFL learners' performance and self-efficacy of reading comprehension and summary writing on grade eight students. (Unpublished PhD dissertation). Bahir Dar University.

Tajzad, M., \& Namaghi, S. (2014). Exploring EFL learners' perceptions of integrated skills approach: A grounded theory. English Language Teaching, 7 (11), 92-98. https://doi.org/10.5539/elt.v7n11p92

Teshome, T., \& Prasana, S. (2016). Students' writing self-efficacy and writing apprehension relating to their writing performance: Reflection on Ethiopian first year university students. International Journal of Humanities, Language and Literature, 3(1), 22-26. https://1ibrary. net/document/z12m6dey-students-efficacy-apprehension-relating-performance-reflectionethiopian-university.html

Vanniarajan, Swathi. (1990). Language learning strategy: What every teacher should know by Rebeca L. Oxford. Issues in Applied Linguistics, 1(1), 115-120. https://doi.org/10.5070/ L411004984

Spack, R. (1985). Literature, reading, writing, and ESL: Bridging the gaps. TESOL Quarterly, 19(4), 703-725. https://doi.org/10.2307/3586672 
Richards, J. C., \& Rodgers, T. S. (1986). Approaches and methods in language teaching. Cambridge University Press. https://www.novaconcursos.com.br/blog/pdf/richards-jack-c.\&-rodgers.pdf

Rosenblatt, L. M. (2004). The transactional theory of reading and writing: Theoretical models and processes of reading. International Reading Association, 48(1), 1363-1398 https://northtrap.wordpress.com/2012/07/15/the-transactional-theory-of-reading-and-writinglouise-m-rosenblatt

Tsai, J. (2006). Connecting reading and writing in college EFL courses. The Internet TESL Journal, 12 (12), 465-485. http://iteslj.org/Articles/Tsai-ReadingWritingConnection.html

Wondifraw, D. (2018). Infusing intellectual standards of critical thinking on students' critical reading performance. (Unpublished $\mathrm{PhD}$ dissertation). Addis Ababa University.

Ayalew Tilahun, Berhanu Simegn, Mulugeta Teka

\section{Die Untersuchung der Praxis vom integrierten Lese- und Schreibunterricht zur Förderung des kritischen Denkens bei EFL-Studenten}

\section{Zusammenfassung}

Das grundlegende Ziel der vorliegenden Arbeit war es, die Praxis des integrierten Leseund Schreibunterrichts im Hinblick auf die Entwicklung des kritischen Denkens bei den EFL-Studenten der Universität Bahir Dar zu untersuchen. Dabei wurde ein quasi-experimentelles Vortest-Nachtest-Design eingesetzt. An der Untersuchung nahmen 96 Studenten im Hauptfach Englisch teil, die nach dem Zufallsprinzip einer Versuchs- $(n=48)$ bzw. einer Kontrollgruppe $(n=48)$ zugeordnet wurden. Die Kontrollgruppe wurde mittels einer separaten Lese- und Schreibmethode unterrichtet, während die Versuchsgruppe 12 Wochen lang drei Stunden pro Woche mittels einer neu entwickelten, integrierten Lese- und Schreibmethode lernte. Anschließend wurden 25 Vor- und Nachtests mit Fragen zum kritischen Denken bearbeitet, um die Entwicklung des kritischen Denkens bei den Studierenden zu bewerten. Zur Überprüfung der Zuverlässigkeit und der internen Konsistenz von den beiden Tests wurden Kappa-Statistiken (Interrater- und Split-Half-Reliabilitätstest) verwendet. Schließlich bediente man sich bei der Datenauswertung eines unabhängigen t-Tests, dessen Ergebnisse zeigten, dass sowohl die Kontroll- als auch die Versuchsgruppe in Bezug auf deren Niveau in den Vortests zum kritischen Denken gleich abschnitten. Allerdings stellte sich am Ende der Untersuchung heraus, dass der integrierte Lese- und Schreibunterricht gegenüber den herkömmlichen Methoden zur Förderung des kritischen Denkens bei Studierenden überlegen ist.

Schlüsselwörter: integrierter Lese- und Schreibunterricht, Sprachpädagogik, Lesekompetenz, Schreibkompetenz, kritisches Denken 
